\title{
Effects of the addition of docosahexaenoic acid and $\alpha$-tocopherol on quality of equine spermatozoa stored at $5^{\circ} \mathrm{C}$
}

\author{
Efeitos da adição de ácido docosahexaenoico e $\alpha$-tocoferol na \\ qualidade do espermatozoide equino armazenados a $5^{\circ} \mathrm{C}$
}

\author{
Breno Fernandes Barreto Sampaio ${ }^{1 *}$; Bruno Gomes Nogueira ${ }^{1}$; Maria Inês Lenz \\ Souza $^{2}$; Eliane Vianna da Costa-e-Silva ${ }^{3}$; Carmem Estefânia Serra Neto Zúccari
}

\section{Highlights:}

Fatty acids can be incorporated to PM increasing its fluidity.

DHA improved the total motility of cooled semen.

DHA showed a paradoxal antioxidant effect.

\begin{abstract}
Plasma membrane composition has impact on phase transition from liquid crystal to gel state of cooled sperm cell. The incorporation of polyunsaturated fatty acids increases its fluidity and can contribute to sperm motility. The aim of this study was to compare the effect of adding docosahexaenoic acid (DHA) and $\alpha$-tocopherol ( $\alpha$-Toh) to the cooling extender, singly or combined, to the equine sperm parameters, submitted to cooling, up to 72 hours. Two ejaculates of ten stallions collected with artificial vagina were used, and evaluated for motility, plasma membrane integrity, chromatin fragmentation, mitochondrial activity and lipid peroxidation, according to the following treatments: C; DHA; $\alpha$-Toh; DHA/ $\alpha-$ Toh; EtOH 100: and EtOH 140 (corresponding to control; $10 \mathrm{ng} \mathrm{mL}^{-1}$ of DHA; $2 \mathrm{mM}$ of $\alpha$-Toh; : $10 \mathrm{ng} \mathrm{mL}^{-1}$ of DHA $+2 \mathrm{mM}$ of $\alpha$-Toh; $100 \mu \mathrm{L}$ of ethanol and $140 \mu \mathrm{L}$ of ethanol respectively). DHA treatment showed higher motility $(68.2 \pm 12.3 ; \mathrm{p}<0.05)$ when compared to control $(62.1 \pm 16.2)$, DHA/ $\alpha$-Toh $(61.3 \pm$ $12.7)$ and EtOH $(58.1 \pm 8.6)$ groups. In lipid peroxidation assay, the control group showed 2,506.2 \pm $796.4 \mathrm{ng}$ of MDA $10^{8}$ spermatozoa $^{-1}$, being significantly higher $(\mathrm{p}<0.05)$ than the groups treated with DHA $(2,036.0 \pm 687.0), \alpha$-Toh $(1,890.8 \pm 749.5)$ and DHA/ $\alpha$-Toh $(1,821.1 \pm 627.2)$. In conclusion, $\alpha$-Toh was effective in diminishing lipid peroxidation of equine sperm subjected to cooling, and DHA improved sperm motility and, in spite of being a polyunsaturated fatty acid with high susceptibility to peroxidation, reduced lipid peroxidation.
\end{abstract}

Key words: Antioxidant. DHA. Stallion. Vitamin E.

\section{Resumo}

A composição da membrana plasmática tem impacto na transição de fase do estado cristal líquido para o estado gel das células espermáticas submetidas à refrigeração. A incorporação de ácidos graxos poliinsaturados aumenta sua fluidez e pode contribuir para a motilidade espermática. O objetivo deste

\footnotetext{
1 Pós-Graduandos, Programa de Pós-Graduação em Ciência Animal, Faculdade de Medicina Veterinária e Zootecnia, Universidade Federal do Mato Grosso do Sul, UFMS, Campo Grande, MS, Brasil. E-mail: breno.sampaio@ufms.br; bruno_ufrrj@hotmail.com 2 Profa $^{a}$, Institudo de Biosciências, UFMS, Campo Grande, MS, Brasil. E-mail: maria.souza@ufms.br

3 Profs., Faculdade de Medicina Veterinária e Zootecnia, UFMS, Campo Grande, MS, Brasil. E-mail: eliane.silva@ufms.br; zuccari@terra.com.br

* Author for correspondence
} 
estudo foi comparar o efeito da adição de ácido docosahexaenóico (DHA) e $\alpha$-tocoferol ( $\alpha$-Toh) ao diluidor de refrigeração, isoladamente ou combinado, aos parâmetros do sêmen equino, submetidos à refrigeração por até 72 horas. Foram utilizados dois ejaculados de dez garanhões coletados com vagina artificial e avaliados quanto à motilidade, integridade da membrana plasmática, fragmentação da cromatina, atividade mitocondrial e peroxidação lipídica, de acordo com os seguintes tratamentos: C; DHA; a-Toh; DHA / a-Toh; EtOH 100: e EtOH 140 (correspondentes ao controle; 10 ng mL-1 de DHA; $2 \mathrm{mM}$ de $\alpha$-Toh;: $10 \mathrm{ng} \mathrm{mL}-1$ de DHA $+2 \mathrm{mM}$ de $\alpha$-Toh; $100 \mu \mathrm{L}$ de etanol e $140 \mu \mathrm{L}$ de etanol, respectivamente). $\mathrm{O}$ tratamento com DHA mostrou maior motilidade $(68,2 \pm 12,3 ; \mathrm{p}<0,05)$ quando comparado aos grupos controle $(62,1 \pm 16,2), \mathrm{DHA} / \alpha-\mathrm{Toh}(61,3 \pm 12,7)$ e EtOH $(58,1 \pm 8,6)$. Na análise de peroxidação lipídica, o grupo controle mostrou 2.506,2 $\pm 796,4 \mathrm{ng}$ de MDA $10^{8}$ espermatozoides $^{-1}$, sendo significativamente maior $(\mathrm{p}<0,05)$ do que os grupos tratados com DHA $(2.036,0 \pm 687,0), \alpha$-Toh $(1.890,8 \pm 749,5)$ e DHA / a-Toh $(1.821,1 \pm 627,2)$. Em conclusão, $\alpha$-Toh foi eficaz na diminuição da peroxidação lipídica de espermatozoide equino submetido ao resfriamento, e o DHA melhorou a motilidade espermática e, apesar de ser um ácido graxo poliinsaturado com alta suscetibilidade à peroxidação, reduziu a peroxidação lipídica

Palavras-chave: Antioxidante. DHA. Garanhão. Vitamina E.

\section{Introduction}

Horse breeders have been frequently using reproduction biotechniques, and one of most common is the artificial insemination (AI) with cooled semen. Usually, storage at $5{ }^{\circ} \mathrm{C}$ allows the use of genetic material within 48 hours, without drastic decreases in fertility (Aurich, 2008).

During the seminal cooling process the lipids of plasma membrane (PM) go through a transition phase between 19 to $8{ }^{\circ} \mathrm{C}$, changing from a liquidcrystalline phase to gel state. This transition alters the composition of PM components, as well as decreases their fluidity, making the spermatozoa more susceptible to cold thermal shock and disruption of PM, affecting the function of sperm cell (Amann \& Pickett, 1987; Aurich, 2005).

The lipid composition of PM determines the temperature at which the transition phase occurs. Higher amounts of polyunsaturated fatty acids (PUFAs) and unsaturation degree unsaturation improve fluidity, keeping this structure in the liquid-crystalline state at lower temperatures when compared to the membranes with more rigid conformation (Giraud, Motta, Boucher, \& Grizard, 2000).

The docosahexaenoic acid (DHA) has 22 carbon atoms and six double bonds in the hydrocarbon chain, which enables high versatility of its spatial presentation allowing changing it at intervals of picoseconds or nanoseconds, and this property favors the PM fluidity (Gawrisch., Eldho, \& Holte, 2003). Mammalian spermatozoa have a high concentration of DHA (Neill \& Masters, 1972; Castellini, Lattaioli, Moroni, \& Minelli, 2000), especially in the tail region, where greater flexibility of PM is necessary due to flagellar movement (Connor, Lin, Wolf, \& Alexander, 1998).

The addition of DHA to the extender promotes its incorporation into sperm PM (Nasiri, Towhidi, \& Zeinoaldini, 2012; Towhidi \& Parks, 2012) and the increasing of PUFAs at the PM may contribute to sperm motility during storage (Takahashi, Itoh, Nishinomiya, Katoh, \& Manabe, 2012). However, the double bonds found in the PUFAs make it susceptible to lipid peroxidation, mainly initiated by the hydroxyl radical, leading to a cascade reaction (Ball \& Vo, 2002). This phenomenon alters de PM fluidity, affecting physiological events related to fertilization, such as the acrosome reaction (Sanocka \& Kurpisz, 2004).

Seminal plasma contents include several substances related to antioxidant protection as catalase, reduced glutathione, glutathione peroxidase, vitamin $\mathrm{C}, \alpha$-tocopherol $(\alpha$-Toh), coenzyme Q, taurine, hypotaurine and pyruvate 
(Ball, 2008). However, semen dilutions reduce the available concentration of these antioxidants (Nasiri et al., 2012), thereby reducing protection against the harmful effects of oxidative stress.

The $\alpha$-Toh can be incorporated into the PM and has the ability to stabilize it, giving it a more organized appearance (Howard, McNeil, \& McNeil, 2011), and preventing free radicals to attack double bonds of PUFAs (Tran, Wong, Lee, Chan, \& Choy, 1996). The addition of $\alpha$-Toh to cooled equine semen resulted in lower levels of lipid peroxidation (Almeida \& Ball, 2005) and its association with DHA improved the motility and sperm viability of cryopreserved bovine semen (Nasiri et al., 2012; Towhidi \& Parks, 2012).

We hypothesize that in vitro supplementation with the association of DHA and $\alpha$-Toh can benefit the cooled equine semen increasing the fluidity of the plasma membrane through the incorporation of this PUFA in the phospholipid bilayer with antioxidant protection provided by $\alpha$-Toh, avoiding the detrimental effects of lipid peroxidation. The results can help in possible modification of the content of cooling extender. The objective of this study was to compare the effects of adding docosahexaenoic acid and $\alpha$-tocopherol, in cooling extender, singly and in combination, on the equine semen variables submitted to cooling for 72 hours.

\section{Material and Methods}

\section{Ethics committee on animal experimentation}

The study and experimental design were approved by the Committee for Animal Experimentation of Federal University of Mato Grosso do Sul (no. 550/2013).

\section{Collection and transport of semen}

This experiment was conducted at the Biotechnology Laboratory of Animal Reproduction, Faculty of Veterinary Medicine and Animal Science of the Federal University of Mato Grosso do Sul located in Campo Grande - MS, Brasil between September 2015 and February 2016 (20²6' 34' S, $54^{\circ} 38^{\prime} 47^{\prime \prime} \mathrm{W}$ ).

For semen collection it was used an artificial vagina Botucatu model, kept in a temperature between 42 and $45{ }^{\circ} \mathrm{C}$, and collected in a phantom or female in estrus. Two ejaculates, with one-week interval between the collections, were used from ten adult stallions, totalizing 20 samples. The stallions were all Quarter Horses breed belonged to 5 horse farms located in Campo Grande - MS and aged between 6 and 17 years, four of them were under or equal 12 years old and six were 13 years old or above this age. They were kept in individual stalls measuring $4.0 \times 4.0 \mathrm{~m}$ and their nutrition was based in concentrate ( $1.5 \%$ of the weight) and alfalfa hay (2.0\% of the weight). The gazing period ranged from two to four hours, according to the farm management. All the stallions had proven fertility and only ejaculates presenting motility $\geq 70 \%$ after collection were processed.

After collection and evaluation of seminal characteristics, an aliquot containing $1.4 \times 10^{9}$ sperm was diluted in commercial skim milk extender (Botusemen $^{\mathrm{TM}}$ ) at a concentration of $50 \times 10^{6}$ sperm $\mathrm{mL}^{-1}$. The transport to the laboratory was made in a container at $15{ }^{\circ} \mathrm{C}$ (Botubox $\left.{ }^{\mathrm{TM}}\right)$, with a maximum interval of 1 hour after collection. The maximum distance from the horse farm to the laboratory was $40 \mathrm{~km}$.

\section{Semen processing and experimental groups}

Semen was subjected to centrifugation at $600 \mathrm{G}$ for 10 minutes in order to remove seminal plasma and diluent. The supernatant was discarded, and the pellet resuspended with the same extender, at a concentration of $50 \times 10^{6}$ spermatozoa $\mathrm{mL}^{-1}$. The final volume was fractionated in seven aliquots containing $200 \times 10^{6}$ sperm, totalizing $4 \mathrm{~mL}$ per group, in which antioxidants and ethanol were added. 
The reagents were added to the diluted semen according to the following experimental groups: $\mathrm{C}$ - control; DHA - $10 \mathrm{ng} \mathrm{mL}^{-1}$ of docosahexaenoic acid; $\alpha$-Toh - 2 mM of $\alpha$-tocopherol; DHA/ $\alpha$-Toh $10 \mathrm{ng} \mathrm{mL}^{-1}$ of docosahexaenoic acid associated with $2 \mathrm{mM}$ of $\alpha$-tocopherol; EtOH $40-40 \mu \mathrm{L}$ of ethanol; EtOH 100 - $100 \mu \mathrm{L}$ of ethanol; EtOH 140 - $140 \mu \mathrm{L}$ of ethanol.

The groups added with different volumes of ethanol correspond to the vehicle control of the solvent of DHA, $\alpha$-Toh and the association of the two compounds, respectively.

The samples were stored at $5{ }^{\circ} \mathrm{C}$ temperature in isothermal container (CP) (Nunes, Zorzatto, Costa e Silva, \& Zúccari, 2008) and kept cooled for 72 hours. At intervals of 24 hours recyclable ice was replaced and the semen samples were taken for laboratory analysis.

\section{Seminal evaluation}

The seminal evaluations were performed before cooling and addition of antioxidants (M-0) and at 24 (M-24), 48 (M-48) and 72 (M-72) hours of cooling. At each time period, $600 \mu \mathrm{L}$ of each treatment were taken and kept in a water bathtub at $37{ }^{\circ} \mathrm{C}$ for 10 minutes. After that, analyzes of subjective motility were carried out, plasma membrane integrity, chromatin fragmentation, mitochondrial activity and lipid peroxidation.

\section{Sperm motility}

The evaluation of motility was through "blind analysis" and performed by the same technician, depositing $10 \mu \mathrm{L}$ of semen between slide and cover slip under $\mathrm{x} 100$ and $\mathrm{x} 400$ magnification with bright field microscopy and kept on a warm plate at $37^{\circ} \mathrm{C}$. The result was expressed in percentage as the total proportion of mobile sperm.

\section{Sperm concentration}

The concentration was estimated after semen collection and prior to cooling, using a dilution rate of 1:100, in Neubauer chamber. The amount was calculated under x 400 magnification with bright field microscopy and the results were expressed in millions of sperm $\mathrm{mL}^{-1}$.

\section{Plasma membrane integrity}

The plasma membrane integrity (PMI) was analyzed according to the technique described by Harrison and Vickers (1990), in wet preparations stained by the association of fluorescent probes 6-carboxyfluorescein diacetate and propidium iodide. The samples were evaluated under x 400 magnification with epifluorescence illumination using excitation filter of $492 \mathrm{~nm}$ and emission at $517 \mathrm{~nm}, 200$ cells counted and classified according to the staining pattern in two categories: intact - cell stained in green along its entire length and; damaged - post acrosomal region stained in red and the acrosome in green or sperm head stained in red.

\section{Mitochondrial activity}

The mitochondrial activity was evaluated using 3,3'-diaminobenzidine (DAB), according to Hrudka (1987) technique. $20 \mu \mathrm{L}$ of semen was incubated with $20 \mu \mathrm{L}$ of the dye for one hour at $37{ }^{\circ} \mathrm{C}$ in dry bath. Then, it was made a smear, fastening it in $10 \%$ formalin for 10 minutes. The slides were analyzed under $\mathrm{x} 1,000$ magnification with phase contrast microscopy. It was counted 200 cells and classified according to the degree of staining of the midpiece into four classes: DAB I - fully stained midpiece, indicating high mitochondrial activity; DAB II - $\geq$ $50 \%$ of the colored midpiece, indicating medium to high mitochondrial activity; DAB III - midpiece part $<50 \%$ colored, indicating low mitochondrial activity and DAB IV - no staining of the midpiece, therefore no mitochondrial activity. 


\section{Chromatin fragmentation}

It was used toluidine blue staining for the analysis of chromatin fragmentation, according to the technique described by Beletti, Costa and Viana (2004). The smears were performed with $25 \mu \mathrm{L}$ of semen and, after air drying, the slides were fixed for one minute in ethanol solution and acetic acid (3:1), then in $70 \%$ ethanol for three minutes, and then hydrolysed for 20 minutes in $4 \mathrm{mmol}$ hydrochloric acid. After hydrolysis, the slides were rinsed with deionized water and dried at room temperature.

For calculating the amount, $20 \mu \mathrm{L}$ toluidine blue solution diluted in $0.025 \%$ McIlvaine buffer was deposited between slide and coverslip. The evaluation was under $\mathrm{x} 1,000$ magnification with bright field microscopy and 500 cells per slide were counted, considering two categories: fragmented chromatin - stained sperm head in violet or dark blue and non-fragmented chromatin - stained sperm head in light blue.

\section{Lipid peroxidation}

The level of lipid peroxidation was indirectly measured by the technique of TBARS (Nichi et al., 2007) which consists in the measurement of thiobarbituric acid reactive species induced with vitamin $\mathrm{C}$ and iron. Spectrophotometry was performed at a wavelength of $532 \mathrm{~nm}$ and the results were compared to a standard malondialdehyde (MDA) curve, previously established. TBARS concentration was determined using a molar extinction coefficient of MDA $\left(1.56 \times 10^{5} \times \mathrm{M} \mathrm{mL}^{-}\right.$ $\left.{ }^{1}\right)$ and expressed in nanograms of MDA per $1 \times 10^{8}$ sperm.

\section{Statistical analysis}

The experimental design was a splitted plot, considering the addition of DHA, $\alpha$-Toh and their associations such as treatment and time points as subplots. To compare the dependent variables (motility, PMI, chromatin fragmentation, mitochondrial activity and lipid peroxidation) it was used analysis of variance, by the statistical SAS GLM procedure, considering the fastened effects of treatment and seminal evaluation time. The means were compared by Duncan test at 5\% significance level. The variables expressed as percentages were transformed into arcsine (x/100) as suggested by Sampaio (2007).

\section{Results and Discussion}

The average values obtained in $\mathrm{M}-0$ for the analyzed variables were: motility - $78.0 \pm 4.1 \%$; intact sperm - $73.1 \pm 15.9 \%$; DAB I $-38.3 \pm$ 17.1\%; fragmented chromatin - $3.9 \pm 1.6 \%$; and lipid peroxidation $-1,543.5 \pm 1,295.2 \mathrm{ng}$ of MDA $10^{8}$ sperm $^{-1}$. There was no significant interaction between the times and the tested treatments, which means that statistical analysis was performed grouping all treatments to compare the effect of time of storage and grouping the results of the three times of sample taken to compare the treatment effect. Figures 1 to 5 show the average values of each treatment in function of moment for each analysed variable. Along the refrigeration period, motility and DAB I variables showed progressive decrease, PM integrity did not differ between M-48 e M-72 moments, but both moments were lower than M-24, and chromatin fragmentation increased in M-72 when compared to M-24. Moreover, lipid peroxidation did not increase during the storage period (Table 1). 
Table 1

Seminal variables of equine semen $(n=20)$ added by docosahexaenoic acid and $\alpha$-tocopherol, summited to cooling at $5^{\circ} \mathrm{C}$ for $72 \mathrm{~h}$ according to the analyzed moments

\begin{tabular}{cccc}
\hline \multirow{2}{*}{ Spermatic Variables } & \multicolumn{3}{c}{ Time of Cooling (hours) } \\
\cline { 2 - 4 } & M-24 & M-48 & M-72 \\
\hline Motility (\%) & $69,6 \pm 12,3^{\mathrm{a}^{* *}}$ & $60,4 \pm 16,3^{\mathrm{b}}$ & $54,6 \pm 18,6^{\mathrm{c}}$ \\
Intact (\%) & $32,0 \pm 11,2^{\mathrm{a}}$ & $26,0 \pm 9,5^{\mathrm{b}}$ & $23,6 \pm 9,9^{\mathrm{b}}$ \\
Fragmented DNA (\%) & $4,3 \pm 1,4^{\mathrm{a}}$ & $4,5 \pm 1,2^{\mathrm{ab}}$ & $4,7 \pm 1,3^{\mathrm{b}}$ \\
DAB I* (\%) & $23,1 \pm 14,6^{\mathrm{a}}$ & $13,7 \pm 8,8^{\mathrm{b}}$ & $8,6 \pm 6,4^{\mathrm{c}}$ \\
TBARS (ng MDA 10 ${ }^{8}$ sptz $^{-1}$ ) & $2.280,4 \pm 841,8$ & $2.178,8 \pm 904,4$ & $2.285,9 \pm 914,1$ \\
\hline
\end{tabular}

* DAB I = high mitochondrial activity according to the classes of 3,3'-diaminobenzidine test; TBARS = thiobarbituric acid reactive species; $\mathrm{MDA}=$ malondialdehyde; $\mathrm{sptz}=$ spermatozoa

** Different letters at the same row indicates significant difference between means by Duncan test $(\mathrm{p}<0.05)$.

Semen samples treated with DHA showed higher motility when compared to groups $\mathrm{C}, \mathrm{DHA} / \alpha-\mathrm{Toh}$ and $\mathrm{EtOH}$, but did not differ from $\alpha$-Toh treatment (Table 2). The results of the addition of $\alpha$-Toh are consistent with those described by Ball, Medina, Gravance and Baumber (2001) and Almeida and Ball (2005), where no difference between control and the supplemented groups with $\alpha$-Toh was found. However, in poor quality human semen, in vitro $\alpha$-Toh addition results in better motility, probably due to the neutralization of reactive oxygen species (ROS) produced in excess by sperm with morphological changes (Keshtgar et al., 2012).

Table 2

Spermatic variables of equine semen $(n=20)$ added by docosahexaenoic acid and $\alpha$-tocopherol, alone or in association, cooled at $5^{\circ} \mathrm{C}$ for $72 \mathrm{~h}$ according to the treatment groups

\begin{tabular}{lcccccc}
\hline \multirow{2}{*}{$\begin{array}{c}\text { Spermatic } \\
\text { Variables }\end{array}$} & $\mathrm{C}^{* *}$ & DHA & $\alpha$-Toh & DHA/ $\alpha$-Toh & Etoh 100 & Etoh 140 \\
\cline { 2 - 6 } Mot (\%)* & $62,1 \pm 16,2^{\mathrm{b} * * *}$ & $68,2 \pm 12,3^{\mathrm{a}}$ & $65,0 \pm 17,7^{\mathrm{ab}}$ & $61,3 \pm 12,7^{\mathrm{b}}$ & $58,1 \pm 8,6^{\mathrm{bc}}$ & $52,3 \pm 20,1^{\mathrm{c}}$ \\
Ínt (\%) & $30,3 \pm 13,0^{\mathrm{a}}$ & $27,2 \pm 9,1^{\mathrm{ab}}$ & $28,6 \pm 11,0^{\mathrm{ab}}$ & $27,4 \pm 10,4^{\mathrm{ab}}$ & $25,9 \pm 10,3^{\mathrm{bc}}$ & $23,4 \pm 8,6^{\mathrm{c}}$ \\
Frag (\%) & $4,6 \pm 1,5$ & $4,3 \pm 1,2$ & $4,3 \pm 1,3$ & $4,1 \pm 1,1$ & $4,7 \pm 1,3^{\mathrm{ab}}$ & $4,9 \pm 1,4^{\mathrm{b}}$ \\
DAB I (\%) & $16,3 \pm 13,2$ & $15,9 \pm 12,7$ & $16,4 \pm 10,4$ & $15,6 \pm 13,0$ & $13,2 \pm 12,4$ & $14,3 \pm 12,2$ \\
TBARS*** & $2.506,2 \pm$ & $2.036,0 \pm$ & $1.890,8 \pm$ & $1.821,1 \pm$ & $2.636,5 \pm$ & $2.599,6^{\mathrm{b}} \pm$ \\
& $796,4^{\mathrm{b}}$ & $687,0^{\mathrm{a}}$ & $749,5^{\mathrm{a}}$ & $627,2^{\mathrm{a}}$ & $1.100,3^{\mathrm{b}}$ & $893,9^{\mathrm{b}}$ \\
\hline
\end{tabular}

$*$ Mot $=$ Motility; Int $=$ Intact; Frag = Fragmented DNA; DAB I $=$ high mitochondrial activity according to the classes of 3,3'-diaminobenzidine; TBARS $=$ thiobarbituric acid reactive species

$* * \mathrm{C}=$ Control; DHA $=$ docosahexaenoic acid $10 \mathrm{ng} \mathrm{mL}-1$; $\alpha$-Toh $=2 \mu \mathrm{M}$ of $\alpha$-tocopherol; DHA $/ \alpha$-Toh $=$ association of docosahexaenoic acid $10 \mathrm{ng} \mathrm{mL}^{-1}$ and $2 \mu \mathrm{M}$ of $\alpha$-tocopherol; EtOH $100=100 \mu \mathrm{L}$ of ethanol, vehicle control of $\alpha$-tocopherol solvent; EtOH $140=140 \mu \mathrm{L}$ of ethanol, vehicle control of docosahexaenoic acid and $\alpha$-tocopherol solvent

$* * *$ Unit of TBARS $=$ ng of malondialdehyde $10^{8}$ spermatozoa $^{-1}$

$* * * *$ Different letters at the same row indicates significant difference between means by Duncan test $(\mathrm{p}<0.05)$. 


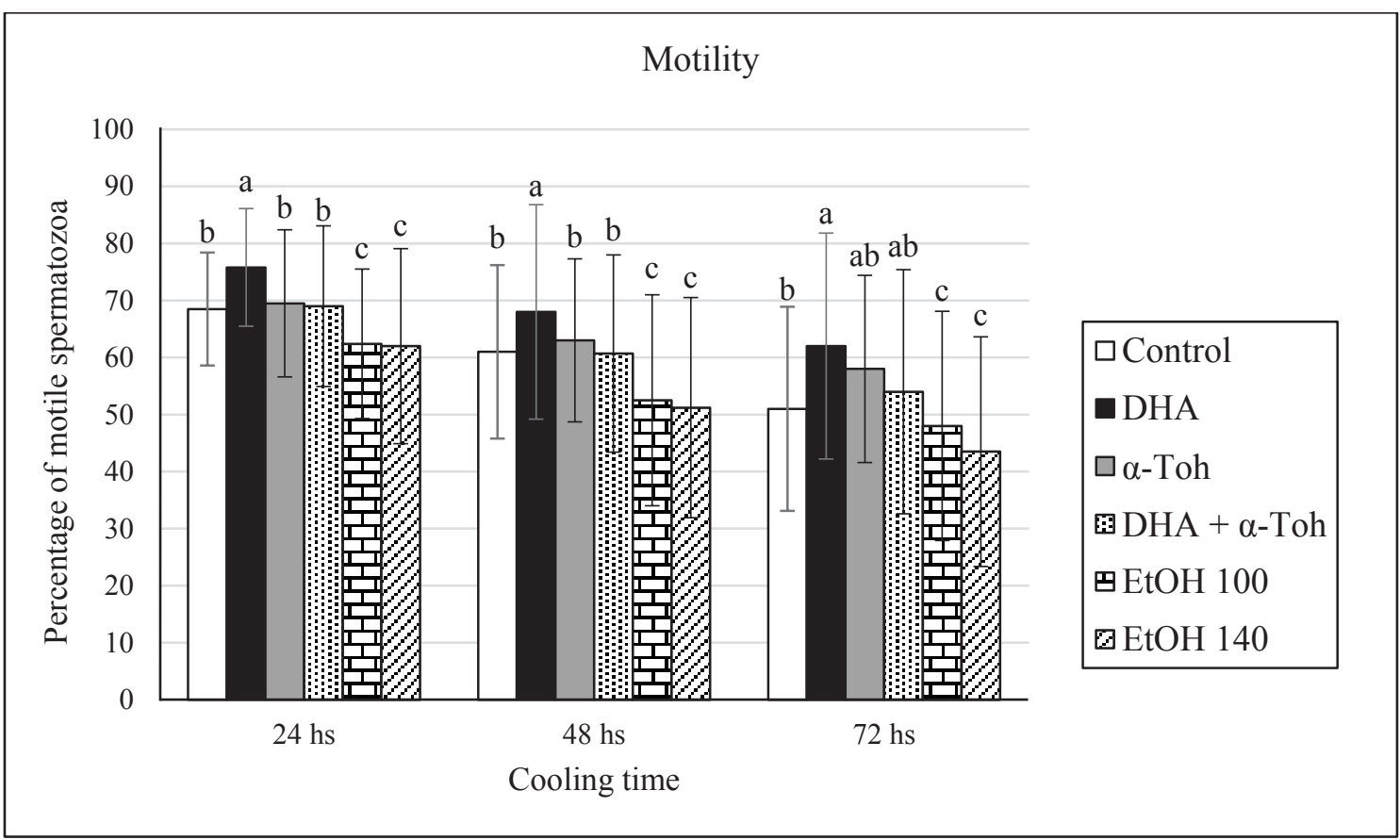

Figure 1. Effect of docosahexaenoic acid (DHA), $\alpha$-tocopherol ( $\alpha$-Toh), singly or in combination, and vehicle control (ethanol - EtOH 100 for isolated compounds and EtOH 140 for the combination of DHA + $\alpha$-Toh) on motility of equine spermatozoa stored under $5^{\circ} \mathrm{C}$ for $72 \mathrm{~h}$. Different letters at the same cooling time indicates significant difference between means by Duncan test $(\mathrm{p}<0.05)$

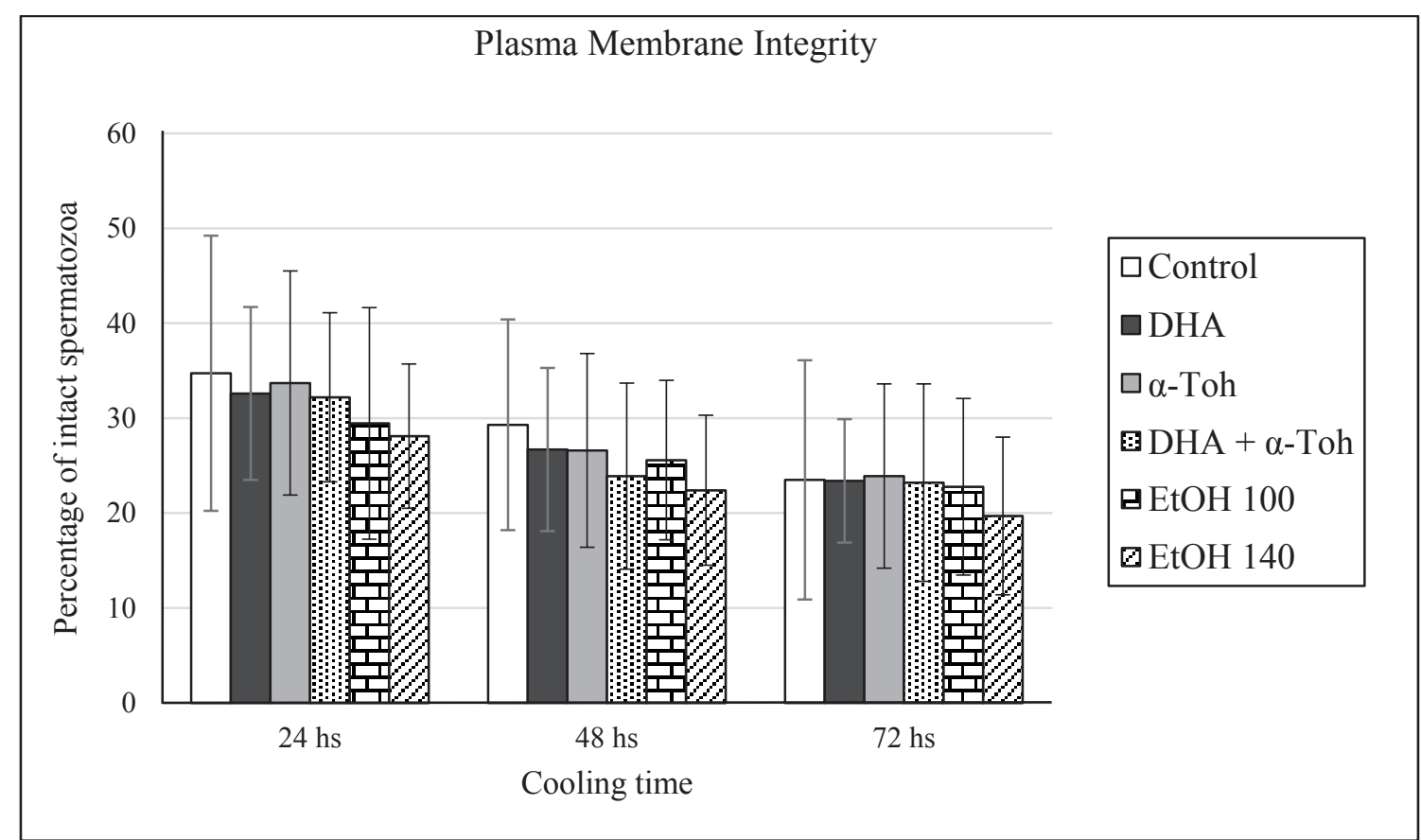

Figure 2. Effect of docosahexaenoic acid (DHA), $\alpha$-tocopherol ( $\alpha$-Toh), singly or in combination, and vehicle control (ethanol - EtOH 100 for isolated compounds and EtOH 140 for the combination of DHA + $\alpha$-Toh) on plama membrane integrity of equine spermatozoa stored under $5^{\circ} \mathrm{C}$ for $72 \mathrm{~h}$. Different letters at the same cooling time indicates significant difference between means by Duncan test $(p<0.05)$ 


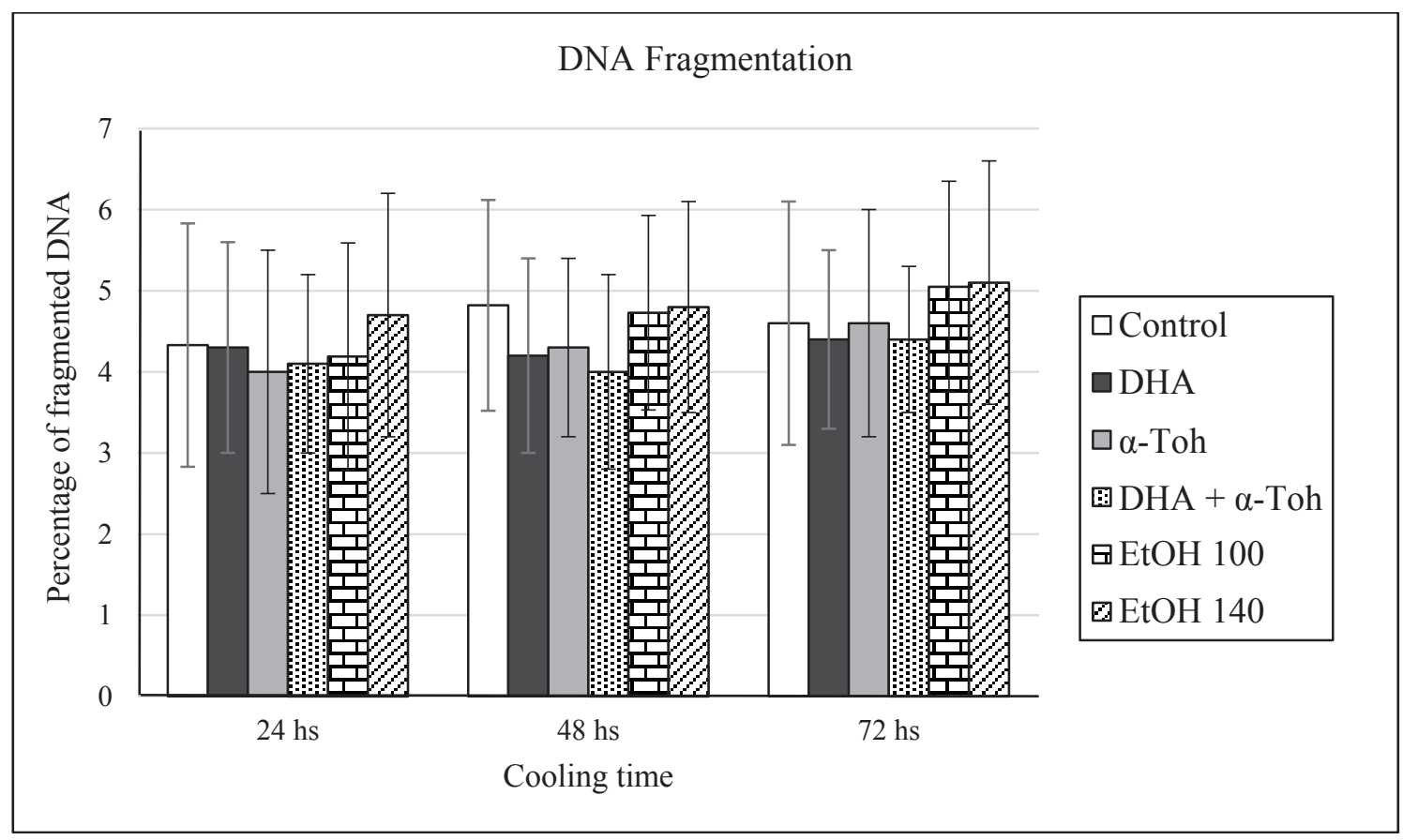

Figure 3. Effect of docosahexaenoic acid (DHA), $\alpha$-tocopherol ( $\alpha$-Toh), singly or in combination, and vehicle control (ethanol - EtOH 100 for isolated compounds and EtOH 140 for the combination of DHA $+\alpha$-Toh) on DNA fragmentation of equine spermatozoa stored under $5^{\circ} \mathrm{C}$ for $72 \mathrm{~h}$. Different letters at the same cooling time indicates significant difference between means by Duncan test $(\mathrm{p}<0.05)$

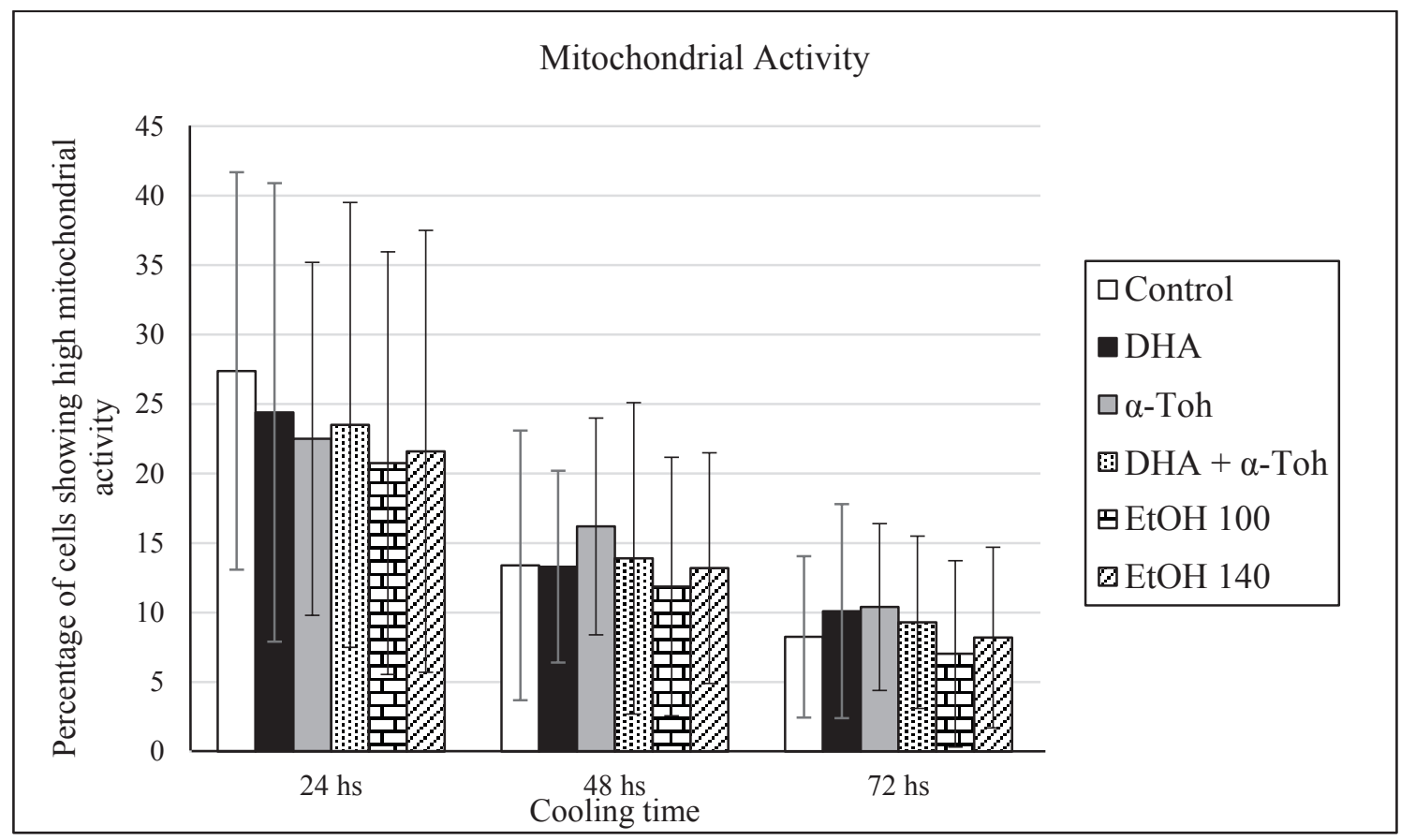

Figure 4. Effect of docosahexaenoic acid (DHA), $\alpha$-tocopherol ( $\alpha$-Toh), singly or in combination, and vehicle control (ethanol - EtOH 100 for isolated compounds and EtOH 140 for the combination of DHA + $\alpha$-Toh) on mitochondrial activity of equine spermatozoa stored under $5^{\circ} \mathrm{C}$ for $72 \mathrm{~h}$. Different letters at the same cooling time indicates significant difference between means by Duncan test $(\mathrm{p}<0.05)$ 


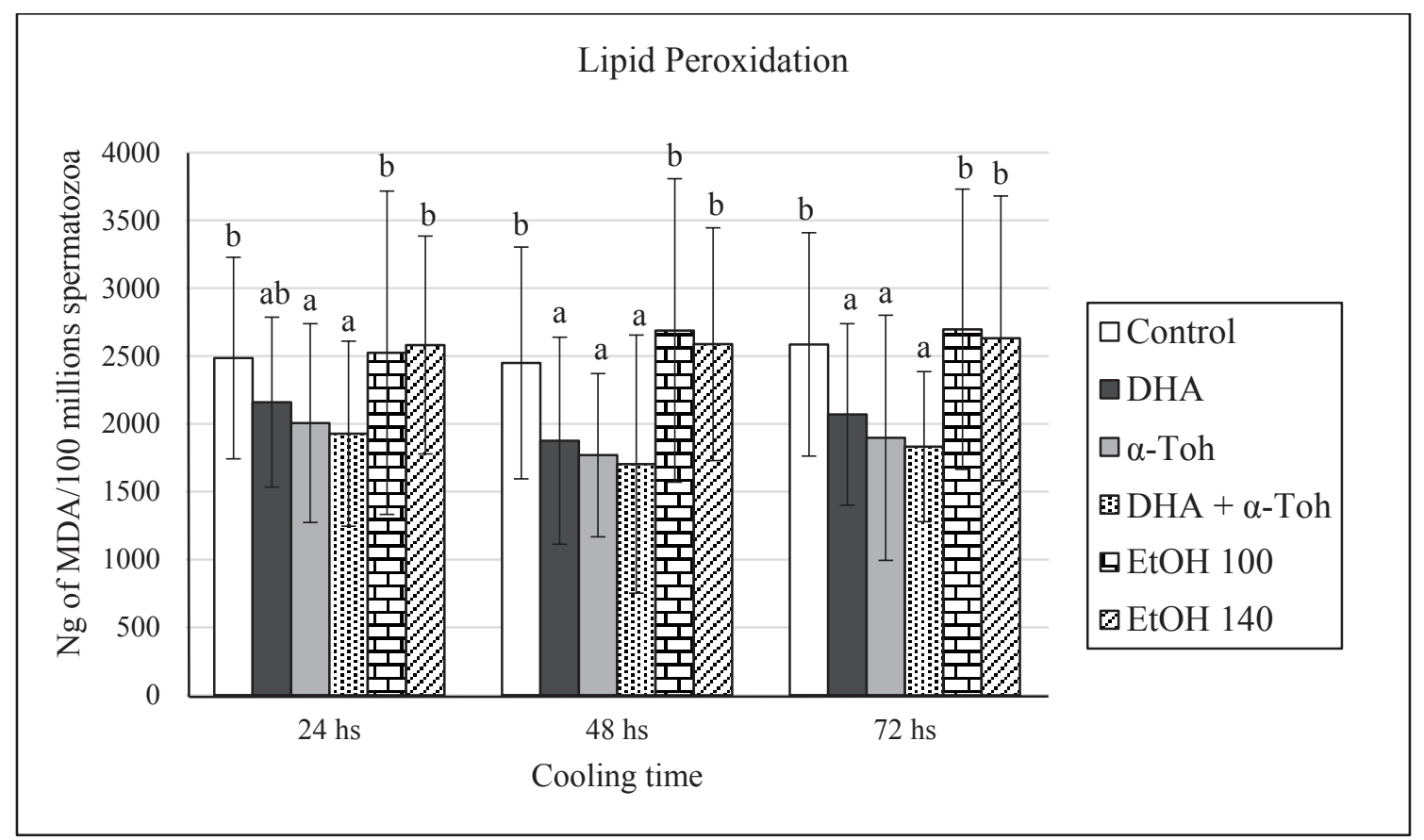

Figure 5. Effect of docosahexaenoic acid (DHA), $\alpha$-tocopherol ( $\alpha$-Toh), singly or in combination, and vehicle control (ethanol - EtOH 100 for isolated compounds and EtOH 140 for the combination of DHA + $\alpha$-Toh) on lipid peroxidation of equine spermatozoa stored under $5^{\circ} \mathrm{C}$ for $72 \mathrm{~h}$. Different letters at the same cooling time indicates significant difference between means by Duncan test $(p<0.05)$

The addition of DHA to the environment promotes the incorporation of this PUFA in cell membranes (Wassall \& Stillwell, 2009), changing its composition by increasing the proportion of n-3:n-6 (Towhidi \& Parks, 2012), as well as PUFAs: saturated fatty acids (Nasiri et al., 2012). Such incorporation increases the fluidity of PM and can contribute to sperm motility (Connor et al., 1998), since the level of DHA in PM is positively correlated with this seminal parameter (Zerbinati et al., 2016). In frozen boar semen (Kaeoket, SangUrai, Thamniyom, Chanapiwat, \& Techakumphu, 2010) and bull epididymal cryopreserved sperm (Losano et al., 2018), the addition of DHA resulted in increased motility and it was attributed to the incorporation of this PUFA to the PM, helping with the membrane phase transition from liquid crystal to gel state. In horses, the use of nutraceutical rich in DHA modified the sperm PM composition, which resulted in a lower decline of motility in cooled semen for 48 hours. Furthermore, in stallions with pre-cooled low motility $(<40 \%)$, this effect was observed at 24 hours of refrigeration (Brinsko et al., 2005). Our results were similar to those found by Silva, Holden, Lyons, Souza and Fair (2017), which had no improvement in motility adding 10 ng $\mathrm{mL}^{-1}$ of DHA combined with $0.02 \mathrm{nM}$ of $\alpha$-Toh. Nevertheless, in this experiment, the in vitro addition of $10 \mathrm{ng} \mathrm{mL} \mathrm{mL}^{-1}$ of DHA singly showed improvement in sperm motility.

The association between DHA and $\alpha$-Toh on frozen bovine semen resulted in increased sperm motility and viability (Nasiri et al., 2012; Towhidi \& Parks, 2012), we hypothesized that the volume of organic solvent used in this experiment exceeded the possible benefit that the association between $\alpha$-Toh and DHA could provide to semen motility during 72 hours of cooling, since vehicle control group of ethanol (EtOH), corresponding, in volume, to the association of the two compounds, decreased sperm motility. 
The addition of $\alpha$-Toh, DHA or their combination, in this experiment, was not effective in giving greater protection to PM. The same was related to Ball et al. (2001), where $\alpha$-Toh isolated did not improve membrane integrity after 72 hours of refrigeration. However, on boar semen, $\alpha$-Toh significantly enhanced sperm viability along 5 days of storage at $19{ }^{\circ} \mathrm{C}$ (Cerolini, Maldjian, Surai, \& Noble, 2000). DHA addition to frozen boar semen increased PMI preservation (Kaeoket et al., 2010). In bull frozen-tawed semen, $10 \mathrm{ng} \mathrm{mL}^{-1}$ or $10 \mu \mathrm{M}$ of DHA had no effect on PMI (Nasiri et al., 2012; Towhidi \& Parks, 2012; Losano et al., 2018), but 3 $\mathrm{ng} \mathrm{mL} \mathrm{mL}^{-1}$ protected PM from injuries due this process (Kaka et al., 2015). Our results were different from those presented by Silva et al. (2017), who found a protective effect on the plasma membrane when adding the combination of DHA and $\alpha$-Toh.

Semen cooling increases the DNA fragmentation (Linfor \& Meyers, 2002). In fact, this was observed in the present experiment between 48 and 72 hours of storage at $5{ }^{\circ} \mathrm{C}$. Even with DNA fragmentation increasing, the averages found in all analyzed moments fall into animals category with high fertility according to Evenson and Jost (2000) rating, in which animals with less than $15 \%$ fragmentation DNA have high fertility; and Love (2005) where the average of DNA fragmentation in high fertility stallion is $12 \%$. In both classifications, the test used for assessing DNA fragmentation was acridine orange, which has significant correlation $(r=0.55)$ with the test toluidine blue (Naves et al., 2004) used in this experiment.

$\mathrm{DAB}$ test evaluates the mitochondrial activity through quantification of cytochrome $\mathrm{C}$ on the midpiece (Hrudka, 1987). This test has not detected any significant difference between treatments, but it has exhibited reduced DAB I class during the storage period, reflecting the energy expenditure. These findings are in agreement with other studies where, in stallions and bulls frozen semen, the addition of $\alpha$-Toh and DHA, respectively, has not affected mitochondrial activity (Baumber, Ball, \& Linfar, 2005; Franco, Chaveiro, Góis, \& Silva, 2013; Losano et al., 2018).

The $\alpha$-Toh can be found both in seminal plasma and in sperm PM (Agarwal, Saleh, \& Bedaiwy, 2003) and has the ability to neutralize the lipid peroxidation chain reaction fighting peroxyl and alkoxyl radicals (Wayner et al., 1987). In this experiment, the addition of $\alpha$-Toh to equine semen cooling extender reduced lipid peroxidation, confirming the results obtained by Almeida and Ball (2005) with cooled stallions semen, Franco et al. (2013) with frozen stallion semen and Cerolini et al. (2000) with boar semen. Oxidative stress increases fragmentation of DNA (Agarwal \& Said, 2003) and can change the fluidity of the PM, resulting in motility and sperm viability decrease. Furthermore, it may even cause premature sperm capacitation (Franco et al., 2013). However, in equine fresh semen, it was found a correlation between ROS and fertility (Gibb, Lambourne, \& Aitken, 2014). The authors consider that the stallion sperm is characterized by "live fast and die young" pattern, thus generating higher level of oxidative stress. Nevertheless, in stored semen, the accumulation of metabolites in the medium can be harmful to sperm.

Differently of other findings (Kaka et al., 2015; Silva et al., 2017; Losano et al., 2018) the addition of DHA to the semen caused an unexpected effect on the lipid peroxidation in this experiment. The fact that this fatty acid has six double bonds makes it more susceptible to attack by ROS. Although, it was observed a decrease in TBARS values which measures the level of lipid peroxidation. Besides, there was no difference observed between the groups supplemented with $\alpha$-Toh, DHA, and the association between $\alpha$-Toh and DHA at lipid peroxidation levels.

In fact, DHA can act as pro-oxidant or as antioxidant (Yavin, 2006). Some tests involving intra-amniotic administration of DHA in rats, shows decreased lipid peroxidation in the central nervous 
system of neonates treated (Green, Glozman, \& Yavin, 2001a; Green, Glozman, Weiner, \& Yavin, 2001b). The mechanism by which DHA promotes antioxidant protection is unclear. The authors have some hypotheses about how this PUFA could act against the harmful effects of ROS: a) the ROS may prefer some specific PUFAs, such as $n-6 ; b$ ) when the DHA is added to the environment, its incorporation into the plasma membrane is made preferably by phosphatidylethanolamine (Stillwell \& Wassall, 2003), and this phospholipid can be classified as a plasmalogen by having a vinyl ether bond at carbon-1 of glycerol. The plasmalogens may have powerful antioxidant activity and are present in high concentrations in the sperm and (Sindelar, Guan, Dallner, \& Ernster, 1999c); another phospholipid that has high affinity for DHA is the phosphatidylserine and, when they are together, there may be an attractive effect for iron ions, reducing its activity in the Fenton reaction, decreasing, then, lipid peroxidation (Yoshida, Terao, Suzuki, \& Takama, 1991; Green et al., 2001b).

Sub-lethal doses of ethanol showed positive results in frozen bull semen (Dodaran et al., 2015), the authors reported higher motility and mitochondrial activity with lower malondialdehyde levels adding $0.09 \%$ of ethanol in the extender. In this paper, the addition of $40 \mu \mathrm{L}$ of ethanol corresponded to $1 \%$ of the volume of semen used in the experimental groups and showed no detrimental effect on the analyzed variables. On the other hand, the addition of $100 \mu \mathrm{L}$ ( $2.5 \%$ of semen volume) seems to be close to the toxicity threshold, since there was reduction on the PMI in the Etoh 100 group, while in the Etoh 140 (3.5\% of semen volume) there was reduction of motility and PMI when compared to the control group, showing higher toxicity.

\section{Conclusions}

It can be concluded that in vitro addition of DHA singly resulted in higher motility but did not improve PMI, chromatin fragmentation and mitochondrial activity. The combination of $10 \mathrm{ng} \mathrm{mL}^{-1}$ of DHA with $0,02 \mu \mathrm{M}$ of $\alpha$-Toh did not differ from control group in motility, PMI, chromatin fragmentation and mitochondrial activity of equine semen submitted to cooling for 72 hours. Furthermore, it was found a non-expected reduction in lipid peroxidation levels of DHA group, similar to the groups treated with $\alpha$-Toh, and association $\alpha$-Toh / DHA, suggesting that DHA may have a paradoxical antioxidant effect on the sperm. New researches are needed to elucidate the effects of DHA on fertility, its use in animals with low reproductive potential and testing other organic solvents as well as the combination with other antioxidants.

\section{Acknowledgement}

Special thanks to FUNDECT for funding the scholarships of post graduate students.

This study was financed in part by the Coordenação de Aperfeiçoamento de Pessoal de Nível Superior - Brasil (CAPES) - Finance Code 001.

\section{Conflicts of interests}

None of the authors have any conflict of interest to declare.

\section{References}

Agarwal, A., \& Said, T. M. (2003). Role of sperm chromatin abnormalities and DNA damage in male infertility. Human Reproduction, 9(4), 331-345. doi: 10.1093/humupd/dmg027

Agarwal, A., Saleh, R. A., \& Bedaiwy, M. A. (2003). Role of reactive oxygen species in the pathophysiology of human reproduction. Fertilily and Sterility, 79(4), 829-843. doi: 10.1016/S0015-0282(02) 04948-8

Amann, R. P., \& Pickett, B. W. (1987). Principles of cryopreservation and a review of cryopreservation of stallion spermatozoa. Journal of Equine Veterinary Science, 7(3), 145-173. doi: 10.1016/S07370806(87)80025-4 
Almeida, J., \& Ball, B. A. (2005). Effect of $\alpha$-tocopherol and tocopherol succinate on lipid peroxidation in equine spermatozoa. Animal Reproduction Science, 87(3-4), 321-337. doi: 10.1016/j. anireprosci.2004.12.004

Aurich, C. (2005). Factors affecting the plasma membrane function of cooled-stored stallion spermatozoa. Animal Reproduction Science, 89(1-4), 65-75. doi: 10.1016/j.anireprosci.2005.06.025

Aurich, C. (2008). Recent advances in cooled-semen technology. Animal Reproduction Science, 107(3-4), 268-275. doi: 10.1016/j.anireprosci.2008.04.015

Ball, B. A., Medina, V., Gravance, C. G., \& Baumber, J. (2001). Effect of antioxidants on preservation of motility, viability and acrosomal integrity of equine spermatozoa during storage at $5^{\circ} \mathrm{C}$. Theriogenology, 56(4), 577-589. doi: 10.1016/ S0093-691X(01)00590-8

Ball, B. A., \& Vo, A. (2002). Detection of lipid peroxidation in equine spermatozoa based upon the lipophilic fluorescent dye C-11-BODIPY581/591. Journal of Andrology, 23(2), 259-269. doi: 10.1002/ j.1939-4640.2002.tb02623.x

Ball, B. A. (2008). Oxidative stress, osmotic stress and apoptosis: impacts on sperm function and preservation in the horse. Animal Reproduction Science, 107(3-4), 257-267. doi: 10.1016/j.anireprosci.2008.04.014

Baumber, J., Ball, B. A., \& Linfar, J. J. (2005). Assessment of the cryopreservation of equine spermatozoa in the presence of enzyme scavengers and antioxidants. American Journal of Veterinary Research, 66(5), 772-779. doi: 10.2460/ajvr.2005.66.772

Beletti, M. E., Costa, L. F., \& Viana, M. P. (2004). Computational approach to characterization of bovine sperm chromatin alterations. Biotechnic and Histochemistry, 79(1), 17-23. doi: 10.1080/10520290410001700774

Brinsko, S. P., Varner, D. D., Love, C. C., Blanchard, T. L., Day, B. C., \& Wilson, M. E. (2005). Effect of feeding DHA-enriched nutraceutical on the quality of fresh, cooled and frozen stallion semen. Teriogenology, 63(5), 1519-1527. doi: 10.1016/j. theriogenology.2004.07.010

Castellini, C., Lattaioli, P., Moroni, M., \& Minelli, A. (2000). Effect of seminal plasma on the characteristics and fertility of rabbit spermatozoa. Animal Reproduction Science, 63(3-4), 275-282. doi: 10.1016/S0378-4320(00)00181-0

Cerolini, S., Maldjian, A., Surai, P., \& Noble, R. (2000). Viability, susceptibility to peroxidation and fatty acid composition of boar semen during liquid storage.
Animal Reproduction Science, 58(1-2), 99-111. doi: 10.1016/S0378-4320(99)00035-4

Connor, W. E., Lin, D. S., Wolf, D. P., \& Alexander, M. (1998). Uneven distribution of desmosterol and docosahexaenoic acid in the heads and tails of monkey sperm. Journal of Lipid Research, 39(7), 1404-1411.

Dodaran, H. V., Zhandi, M., Sharafi, M., Nejati-Amiri, E., Nejati-Javaremi, A., Mohammadi-Sangcheshmeh, A., Shakeri, M. (2015). Effect of ethanol induced mild stress on post-thawed bull sperm quality. Cryobiology, 71(1), 12-17. doi: 10.1016/j. cryobiol.2015.06.008

Evenson, D. P. \& Jost, L. (2000). Sperm chromatin structure assay is useful for fertility assessment. Methods in Cell Science, 22(2-3), 169-189.

Franco, J. S. V., Chaveiro, A., Góis, A., \& Silva, F. M. (2013). Effects of $\alpha$-tocopherol and ascorbic acid on equine semen quality after cryopreservation. Journal of Equine Veterinary Science, 33(10), 787-793. doi: 10.1016/j.jevs.2012.12.012

Gawrisch, K., Eldho, N. V., \& Holte, L. L. (2003). The structure of DHA in phospholipid membranes. Lipids, 38(4), 445-452. doi: 10.1007/s11745-0031082-0

Gibb, Z., Lambourne, S. R., \& Aitken, R. J. (2014). The paradoxical relationship between stallion fertility and oxidative stress. Biology of Reproduction, 91(3), 1-10. doi: 10.1095/biolreprod.114.118539

Giraud, M. N., Motta, C., Boucher, D., \& Grizard, G. (2000). Membrane fluidity predicts the outcome of cryopreservation of human spermatozoa. Human Reproduction, 15(10), 2160-2164. doi: 10.1093/ humrep/15.10.2160

Green, P., Glozman, S., \& Yavin, E. (2001a). Ethyl docosahexaenoate-associated decrease in fetal brain lipid peroxide production is mediated by activation of prostanoid and nitric oxide pathways. Biochimica et Biophysica Acta, 1531(1-2), 156-164. doi: 10.1016/ S1388-1981(01)00101-9

Green, P., Glozman, S., Weiner, L., \& Yavin, E. (2001b). Enhanced free radical scavenging and decreased lipid peroxidation in the rat fetal brain after treatment with ethyl docosahexaenoate. Biochimica et Biophysica Acta, 1532(3), 203-212. doi: 10.1016/ S1388-1981(01)00132-9

Harrison, R. A. P., \& Vickers, S. E. (1990). Use of fluorescent probes to assess membrane integrity in mammalian spermatozoa. Journal of Reproduction and Fertility, 88(1), 343-352. doi: 10.1530/ jrf.0.0880343 
Howard, A. C., McNeil, A. K. \& McNeil, P. L. (2011). Promotion of plasma membrane repair by vitamin E. Nature Communications, 20, 1-8. doi: 10.1038/ ncomms 1594

Hrudka, F. (1987). Cytochemical and ultracytochemical demonstration of cytochrome $\mathrm{c}$ oxidase in spermatozoa and dynamics of its changes accompanying ageing or induced by stress. International Journal of Andrology, 10, 809-828. doi: 10.1111/j.1365-2605.1987.tb00385.x

Kaeoket, K., Sang-Urai, P., Thamniyom, A., Chanapiwat, P., \& Techakumphu, M. (2010). Effect of docosahexaenoic acid on quality of cryopreserved boar semen in different breeds. Reproduction in Domestic Animals, 45(3), 458-463. doi: 10.1111/j.1439-0531.2008.01239.x

Kaka, A., Haron, W., Yusoff, R., Yimer, N., Khumran, A. M., Sarsaifi, K., Ebrahimi, M. (2015). Effect of docosahexanoic acid on quality of frozen-thawed bull semen in BioXcell extender. Reproduction, Fertility and Development, 29(3), 490-495. doi: 10.1071/RD15089

Keshtgar, S., Fanaei, H., Bahmanpour, S., Azad, F., Ghannadi, A., \& Kazeroni, M. (2012). In vitro effects of a-tocopherol on teratozoospermic semen samples. Andrologia, 44(1), 721-727. doi: 10.1111/j.14390272.2011.01256.x

Linfor, J. J., \& Meyers, S. A. (2002). Detection of DNA damage in response to cooling injury in equine spermatozoa using single-cell gel electrophoresis. Journal of Andrology, 23(1), 107-113. doi: 10.1002/ j.1939-4640.2002.tb02603.x

Losano, J. D. A., Angrimani, D. S. R., Rui, B. R., Bicudo, L. C., Dalmazzo, A., Silva, B. C. S., Nichi, M. (2018). The addition of docosahexaenoic acid (DHA) and antioxidants (glutathione peroxidase and superoxide dismutase) in extenders to epididymal sperm cryopreservation in bulls. Zygote, 26(3), 199206. doi: 10.1017/S0967199418000096

Love, C. C. (2005). The sperm chromatin structure assay: a review of clinical applications. Animal Reproduction Science, 89(1-4), 39-45. doi: 10.1016/j. anireprosci.2005.06.019

Nasiri, A. H., Towhidi, A., Zeinoaldini, S. (2012). Combined effect of DHA and $\alpha$-tocopherol supplementation during bull semen cryopreservation on sperm characteristics and fatty acid composition. Andrologia, 44(1), 550-555. doi: 10.1111/j.14390272.2011.01225.x
Naves, C. S., Beletti, M. E., Duarte, M. B., Vieira, R. C., Diniz, E. G., \& Jacomini, J. O. (2004). Avaliação da cromatina espermática em equinos com azul de toluidina e acridine orange. Bioscience Journal, 20(3), 117-124.

Neill, A. R., \& Masters, C. J. (1972). Metabolism of fatty acids by bovine spermatozoa. Biochemical Journal, 127(2), 375-385. doi: 10.1042/bj1270375

Nichi, M., Goovaerts, I. G. F., Cortada, C. N. M., Barnabe, V. H., De Clercq, J. B. P., \& Bols, P. E. J. (2007). Roles of lipid peroxidation and cytoplasmic droplets on in vitro fertilization capacity of sperm collected from bovine epididymis stored at 4 and $34^{\circ} \mathrm{C}$. Theriogenology, 67(2), 334-340. doi: 10.1016/j. theriogenology.2006.08.002

Nunes, D. B., Zorzatto, J. R., Costa e Silva, E. V., \& Zúccari, C. E. S. N. (2008). Efficiency of short-term storage of equine semen in a simple-design cooling system. Animal Reproduction Science, 104(2-4), 434-439. doi: 10.1016/j.anireprosci.2007.06.022

Sampaio, I. B. M. (2007). Estatística aplicada à experimentação animal (3a ed.) Belo Horizonte: Fundação de Ensino e Pesquisa em Medicina Veterinária e Zootecnia.

Sanocka, D., \& Kurpisz, M. (2004). Reactive oxygen species and sperm cells. Reproductive Biology and Endocrinology, 2(12), 1-7. doi: 10.1186/1477-78272-12

Silva, D. M., Holden, S. A., Lyons, A., Souza, J. C., \& Fair, S. (2017). In vitro addition of docosahexaenoic acid improves the quality of cooled but not frozenthawed stallion semen. Reproduction, Fertility and Development, 29(10), 2021-2027. doi: 10.1071/ RD16473

Sindelar, P. J., Guan, Z., Dallner, G., \& Ernster, L. (1999). The protective role of plasmalogens in ironinduced lipid peroxidation. Free Radical Biology and Medicine, 26(3-4), 318-324. doi: 10.1016/ s0891-5849(98)00221-4

Stillwell, W., \& Wassall, S. R. (2003). Docosahexaenoic acid: membrane properties of a unique fatty acid. Chemistry and Physics of Lipids, 126(1), 1-27. doi: 10.1016/S0009-3084(03)00101-4

Takahashi, T., Itoh, R., Nishinomiya, H., Katoh, M., \& Manabe, N. (2012). Effect of linoleic acid albumin in a dilution solution and long-term equilibration for freezing of bovine spermatozoa with poor freezability. Reproduction in Domestic Animals, 47(1), 92-97. doi: 10.1111/j.1439-0531.2011.01806.x 
Towhidi, A., \& Parks, J. E. (2012). Effect of n-3 fatty acids and $\alpha$-tocopherol on post-thaw parameters and fatty acid composition of bovine sperm. Journal of Assisted Reproduction and Genetics, 29(10), 10511056. doi: 10.1007/s10815-012-9834-7

Tran, K., Wong, J. T., Lee, E., Chan, A. C., \& Choy, P. C. (1996). Vitamin E potentiates arachidonate release and phospholipase A2 activity in rat heart myoblastic cells. Biochemical Journal, 319(2), 385-391. doi: 10.1042/bj3190385

Wassall, S. R., \& Stillwell, W. (2009). Polyunsaturated fatty acid cholesterol interactions: domain formation in membranes. Biochimica et Biophysica Acta, 1788(1), 24-32. doi: 10.1016/j.bbamem.2008.10.011

Wayner, D. D. M., Burton, G. W., Ingold, K. U., Barclay, L. R. C., \& Locke, S. J. (1987). The relative contributions of vitamin $\mathrm{E}$, urate, ascorbate and proteins to the total peroxyl radical-trapping antioxidant activity of human blood plasma. Biochimica et Biophysica Acta, 924(3), 408-419. doi: 10.1016/0304-4165(87)90155-3
Yavin, E. (2006). Docosahexaenoic acid: a pluripotent molecule acting as a membrane fluidizer, a cellular antioxidant and a modulator of gene expression. Nutrition and Health, 18(3), 261-262. doi: $10.1177 / 026010600601800308$

Yoshida, K., Terao, J., Suzuki, T., \& Takama, K. (1991). Inhibitory effect of phosphatidylserine on irondependent lipid peroxidation. Biochemical and Biophysical Research Communications, 179(2), 1077-1081. doi: 10.1016/0006-291x(91)91929-7

Zerbinati, C., Caponecchia, L., Rago, R., Leoncini, E., Bottaccioli, A. G., Ciacciarelli, M., Iuliano, L. (2016). Fatty acids profiling reveals potential candidate markers of semen quality. Andrology, 4(6), 1094-1101. doi: 10.1111/andr.12236 